\title{
Cardiac responses to elevated seawater temperature in Atlantic salmon
}

\author{
Sven Martin Jørgensen ${ }^{1}$, Vicente Castro², Aleksei Krasnov', Jacob Torgersen', Gerrit Timmerhaus', \\ Ernst Morten Hevrøy ${ }^{3}$, Tom Johnny Hansen ${ }^{4}$, Sissel Susort ${ }^{5}$, Olav Breck ${ }^{6}$ and Harald Takle ${ }^{1,2^{*}}$
}

\begin{abstract}
Background: Atlantic salmon aquaculture operations in the Northern hemisphere experience large seasonal fluctuations in seawater temperature. With summer temperatures often peaking around $18-20^{\circ} \mathrm{C}$ there is growing concern about the effects on fish health and performance. Since the heart has a major role in the physiological plasticity and acclimation to different thermal conditions in fish, we wanted to investigate how three and eight weeks exposure of adult Atlantic salmon to $19^{\circ} \mathrm{C}$, previously shown to significantly reduce growth performance, affected expression of relevant genes and proteins in cardiac tissues under experimental conditions.

Results: Transcriptional responses in cardiac tissues after three and eight weeks exposure to $19^{\circ} \mathrm{C}$ (compared to thermal preference, $14^{\circ} \mathrm{C}$ ) were analyzed with cDNA microarrays and validated by expression analysis of selected genes and proteins using real-time $\mathrm{QPCR}$ and immunofluorescence microscopy. Up-regulation of heat shock proteins and cell signaling genes may indicate involvement of the unfolded protein response in long-term acclimation to elevated temperature. Increased immunofluorescence staining of inducible nitric oxide synthase in spongy and compact myocardium as well as increased staining of vascular endothelial growth factor in epicardium could reflect induced vascularization and vasodilation, possibly related to increased oxygen demand. Increased staining of collagen I in the compact myocardium of $19^{\circ} \mathrm{C}$ fish may be indicative of a remodeling of connective tissue with long-term warm acclimation. Finally, higher abundance of transcripts for genes involved in innate cellular immunity and lower abundance of transcripts for humoral immune components implied altered immune competence in response to elevated temperature.
\end{abstract}

Conclusions: Long-term exposure of Atlantic salmon to $19^{\circ} \mathrm{C}$ resulted in cardiac gene and protein expression changes indicating that the unfolded protein response, vascularization, remodeling of connective tissue and altered innate immune responses were part of the cardiac acclimation or response to elevated temperature.

Keywords: Temperature, Thermal acclimation, Cardiac tissue, Gene expression, Microarray, Immunofluorescence microscopy, iNOS, VEGF, Collagen I, Immune response

\section{Background}

Environmental temperature has been termed the master abiotic factor which controls and limits all biochemical, physiological and life history activities in teleost fishes [1]. The thermal optimum for different species have been extensively studied, representing the temperature where the difference between routine and maximum metabolic rates is greatest; i.e. the aerobic scope is at its maximum [2]. For Atlantic salmon (Salmo salar L.), optimum temperature

\footnotetext{
* Correspondence: harald.takle@nofima.no

'Nofima AS, P.O. Box 210, N-1431 Ås, Norway

${ }^{2}$ AVS Chile S.A., Casilla 300, Puerto Varas, Chile

Full list of author information is available at the end of the article
}

for growth in sea has been found to occur at $13-15^{\circ} \mathrm{C}$ [3], with upper critical temperatures around $22^{\circ} \mathrm{C}$ [4]. In response to natural temperature fluctuations outside of the thermal tolerance window, fish respond by behavioral, biochemical and physiological modifications in order to maintain cellular homeostasis and physiological performance [5,6]. As the key organ supplying oxygen and fuels to the circulatory system for energy production, the heart has a major role in the physiological plasticity and acclimation to different thermal conditions in fish, showing alterations in cardiorespiratory performance, myocardial morphology and expression and phosphorylation of structural genes and proteins [7-10]. The occurrence of a

\section{Biomed Central}


thermal optimum $\left(T_{\text {opt }}\right)$ for cardiovascular function is reflected by different salmonid species having different $T_{\text {opt }}$ for maximum oxygen uptake, aerobic scope and critical swimming speed [11,12]. At temperatures below and above $T_{\text {opt }}$ the scope for aerobic metabolism will decline until a critical temperature $\left(T_{\text {crit }}\right)$ is reached, where no aerobic activity can be performed besides routine metabolism [1]. In salmonids, the decreased aerobic scope observed with increasing temperatures above $T_{\text {opt }}$ is associated with a limited oxygen supply suggested to be caused by a failure in maximum cardiac output to increase above $T_{\text {opt }}$ [13] Acclimation to high temperatures has been associated with cardiac remodeling of tissue composition and morphology [10], which is assumed to compensate for the decreased power-generating ability [14]. The nitric oxide synthase (NOS) system is another important inter- and intracellular regulator of cardiac function and oxygen supply in fish [15], and in long-term warm acclimated eel (Anguilla anguilla) inhibition of NO production significantly reduced the Frank-Starling response [16]. Another interesting yet poorly understood aspect of cardiac responses to temperature increase in fish is the effects on hematological and immunological responses, which may have a significant impact on the health and disease performance of Atlantic salmon in aquaculture, since heart is a target organ for several harmful viral pathogens $[17,18]$.

In Atlantic salmon aquaculture in the Northern hemisphere, fish are exposed to large seasonal fluctuations in seawater temperature. Peak summer temperatures around $18-20^{\circ} \mathrm{C}$ are regularly experienced at production sites in the western and southern regions of Norway, causing concerns regarding the possible negative impact on productivity, fish performance and welfare. We recently reported that long-term exposure (56 days, simulating a warm water period in aquaculture) of adult $(\sim 2 \mathrm{~kg})$ Atlantic salmon to $19^{\circ} \mathrm{C}$ under controlled conditions significantly reduced growth performance when compared to fish reared at $14^{\circ} \mathrm{C}$, a difference driven by a $50 \%$ reduction in feed intake [19]. The objective of the present study was to investigate effects of such temperature increase on molecular responses in cardiac tissues from the same experimental fish. To achieve this, cDNA microarray screening and single gene expression validation with real-time qPCR were employed to evaluate transcriptional changes after 21 days (simulating a short warm water period) and 56 days (simulating a long warm water period) thermal acclimation. In addition, expression of selected proteins of interest were analysed with immunofluorescence microscopy in cardiac tissues after long-term thermal acclimation.

\section{Methods}

\section{Temperature challenge trial}

The experimental design is described in detail elsewhere [19]. This study used half of the groups; those fed the standard diet (L34). In brief, 170 adult $(\sim 1.6 \mathrm{~kg})$ immature Atlantic salmon of the Norwegian salmon procreation strain (NLA) were randomly selected from sea cages and distributed into six $5.3 \mathrm{~m}^{3}$ light-gray round tanks (3 m diameter $\times 0.75 \mathrm{~m}$ water depth, temperature $\left.14^{\circ} \mathrm{C}\right)$ at Matre Research Station, Matre $\left(61^{\circ} \mathrm{N}\right)$, Norway. After 50 days acclimation period all fish were weighed (average body weight $2.0 \pm 0.4 \mathrm{~kg}$ ), and the temperature in three of the tanks was increased to $19^{\circ} \mathrm{C}$ at a rate of $1^{\circ} \mathrm{C}$ per day, while the three remaining tanks were kept at $14^{\circ} \mathrm{C}$. Fish were reared under simulated natural photoperiod in $35 \mathrm{~g} \mathrm{~L}^{-1}$ seawater and oxygen level was kept constant on $90 \%$ saturation (measured continuously in the water outlet) by adding oxygen-supersaturated seawater (350\% saturation). Fish were fed by automatic feeders that were adjusted daily to maintain $10 \%$ in excess. Feed which were not eaten were collected in an outlet trap. Feed was offered between 8 and 9 am and between 1 and $2 \mathrm{pm}$. To standardize sampling, all fish were fed ad libitum exactly four hours before sampling. Individually sampled fish ( 3 per tank, $N=9$ ) were killed by a blow to the head and weights and fork lengths were measured to the nearest $\mathrm{g}$ and nearest $0.5 \mathrm{~cm}$ at the start, 21 days, and 56 days after commencement of the temperature increase. On days 0, 21 and 56, heart samples were collected from all sampled individuals under sterile conditions and divided in two; one half was flashfrozen in liquid nitrogen and stored at $-80^{\circ} \mathrm{C}$ for gene expression analyses while the other half was fixed in $4 \%$ paraformaldehyde for immunofluorescence microscopy. The trial was approved by The National Animal Research Authority according to the 'European Convention for the Protection of Vertebrate Animals used for Experimental and other Scientific Purposes' (EST 123).

\section{RNA extraction}

Sampled hearts for gene expression analyses were stored at $-80^{\circ} \mathrm{C}$ prior to RNA extraction. Standardized tissue sections of $10 \mathrm{mg}$ (equal mix of ventricle and atrium) were prepared under sterile/RNase-free conditions and transferred directly to $1 \mathrm{ml}$ chilled TRIzol (Invitrogen, Carlsbad, CA, USA) in $2 \mathrm{ml}$ tubes with screw caps (Precellys ${ }^{\oplus} 24$, Bertin Technologies, Orléans, France). Two steel beads ( $2 \mathrm{~mm}$ diameter) were added to each tube and the tissue was homogenized in a Precellys ${ }^{\circledR} 24$ homogenizer for two times $25 \mathrm{sec}$ at 5000 rounds per minute with a break of $5 \mathrm{sec}$ between rounds. RNA was extracted from the homogenized tissues using PureLink RNA Mini kits according to the protocol for TRIzol-homogenized samples (Invitrogen). The concentration of extracted total RNA was measured using NanoDrop 1000 Spectrometer (Thermo Scientific, Waltham, MA, USA), while RNA integrity was determined using Agilent 2100 Bioanalyzer with RNA Nano kits (Agilent Technologies, Santa Clara, 
CA, USA). Only samples with a RNA integrity number (RIN) of 8 or higher were accepted.

\section{Microarray analysis}

Two microarrays were used for screening of transcriptional responses to high temperature $\left(19^{\circ} \mathrm{C}\right)$ at both 21 and 56 days after temperature was raised from control $\left(14^{\circ} \mathrm{C}\right)$. Each control and high temperature group consisted of a pool of 9 fish randomly selected from triplicate tanks per each time point. The salmonid fish cDNA microarray SFA2.0 (GEO Omnibus GPL6154) includes 1,800 genes, each printed in six spot replicates. Synthesis of cDNA and hybridizations were carried out as previously described [20]. In brief, samples with $10 \mu \mathrm{g}$ RNA in each were labeled with Cy3-dUTP (reference control, $14^{\circ} \mathrm{C}$ groups) and $\mathrm{Cy} 5$-dUTP (test, $19^{\circ} \mathrm{C}$ groups) (Amersham Biosciences, UK) during cDNA synthesis using the SuperScript III reverse transcriptase kit (Invitrogen). After hybridization, slides were washed in $0.5 \times \mathrm{SSC} / 0.1 \%$ SDS (15 $\mathrm{min}), 0.5 \times \mathrm{SSC} / 0.01 \% \mathrm{SDS}(15 \mathrm{~min})$, and twice in $0.06 \times$ SSC ( 3 min each) at room temperature in dim lighting with gentle agitation. Slides were dried using Array $I^{\circ}$ Microarray High-Speed Centrifuge. Scanning was performed with GenePix 4100A microarray scanner (Molecular Devices, CA, USA) at $5 \mu \mathrm{m}$ resolution and with manually adjusted laser power to ensure an overall intensity ratio close to unity between $\mathrm{Cy} 3$ and $\mathrm{Cy} 5$ channels, and with minimal saturation of features. Images were processed with GenePix Pro 6.0 software. Spots were filtered by criterion $(\mathrm{I}-\mathrm{B}) /(\mathrm{SI}+\mathrm{SB}) \geq 0.6$, where $\mathrm{I}$ and $\mathrm{B}$ are mean signal and background intensities and SI and SB are standard deviations, respectively. Low-quality spots were excluded from analyses and genes with less than three high-quality spots on a slide were discarded. After subtraction of median background from median signal intensities and Lowess normalization, differential expression was assessed by difference of the mean $\log _{2}$-ER (expression ratios, high versus control temperature groups) from zero (six spot replicates per each gene; Student's $t$-test, $\mathrm{p}<$ 0.01). Complete data are provided in the GEO Omnibus (accession number GSE53908). Genes with $\log _{2}$-ER $>0.4$ in at least one time point and common functional annotation according to the STARS program [21] were considered for interpretation in the Results section.

\section{Quantitative real-time RT-PCR (qPCR)}

Experiments were conducted according to the MIQE guidelines [22]. Synthesis of cDNA was performed on $0.2 \mu \mathrm{g}$ DNAse-treated total RNA (Turbo DNA-free ${ }^{\mathrm{Tm}}$, Ambion, Austin, TX, USA) using the TaqMan ${ }^{\circ}$ Gold Reverse Transcription kit (Applied Biosystems, Foster City, CA, USA) in $25 \mu$ l reactions with random hexamer priming according to manufacturer's protocol. Complementary DNA was stored undiluted at $-80^{\circ} \mathrm{C}$ in aliquots to avoid repeated freeze-thawing. To avoid risk for presence of residual DNA contamination, control reactions without RT were tested and GPCR primers were designed to span introns when possible. Oligonucleotide primers for genes of Atlantic salmon were designed with the program eprimer3 from the EMBOSS program package (version 5.0.0, http://emboss.sourceforge.net/). Amplicon size was set to 80-200 and melting temperature to $59-61^{\circ} \mathrm{C}$. Primers were purchased from Invitrogen (Table 1). In silico analysis of gene targets was performed using the STARS program for BLAST and sequence alignments. PCR amplicon size and specificity were confirmed by gel electrophoresis and melting curve analysis (Tm calling; LightCycler 480, Roche Diagnostics, Mannheim, Germany). QPCR was conducted in duplicate reactions as previously described [23]. Cycle threshold $\left(C_{T}\right)$ values were calculated using the fit point method. Duplicate measurements that differed more than $0.5 \mathrm{C}_{\mathrm{T}}$ values were removed and reanalyzed. For relative quantification, the mean of duplicates was used. Relative gene expression ratios of test samples versus the average of the normalized controls $\left(14^{\circ} \mathrm{C}\right)$ were calculated according to the Pfaffl method [24] with normalization using the following reference genes: $N A D H$ dehydrogenase (ubiquinone) 1 beta subcomplex $19 \mathrm{kDa}$ and SEC13-like protein (used for all genes except HSP70),

\section{Table 1 Genes and primer sequences used for qPCR} analyses

\begin{tabular}{cccc}
\hline Gene & Dir. & Primer sequence (5'-3') & GenBank acc. no. \\
\hline HSP70 $^{1}$ & F & TGACGTGTCCATCCTGACCAT & BT043589.1 \\
& R & CTGAAGAGGTCGGACACATCTC & \\
PGC1A $^{2}$ & F & GTCAATATGGCAACGAGGCTC & FJ710605 \\
& R & TCGAATGAAGGCAATCCGTC & \\
CPT1 $^{3}$ & F & TCCCACATCATCCCCTTCAACT & AM230810 \\
& R & TGTCCCTGAAGTAGCCAGCT & \\
HBB $^{4}$ & F & ACAAACGTCAACATGGTCGACTGG & EG897325.1 \\
& R & TCTTCCCCACAGGCCTACGAT & \\
HBA $^{5}$ & F & AAGGCAGATGTCGTCGGTGCT & CK883845.1 \\
& R & CAGCCCAGTGGGAGAATAGGTCT & \\
CD8A $^{6}$ & F & CGTCTACAGCTGTGCATCAATCAA & AY693391 \\
& R & GGCTGTGGTCATTGGTTAGTC & \\
SEC13 $^{7}$ & F & AGTGGGCCTGTATCAGCGACGT & EG882700.1 \\
& R & ATCACTGCTCGTTCGTCGCTCC & \\
NDUFB8 $^{8}$ & F & TCTGTCGCTGGGAGGAGAAGGA & DW532752.1 \\
& R & GTCCAGGCAGGTCCGATACTCTGT & \\
EF1A $^{9}$ & F & CACCACCGGCCATCTGATCTACAA & AF321836 \\
& R & TCAGCAGCCTCCTTCTCGAACTC & \\
\hline
\end{tabular}

Complete gene names: ${ }^{1}$ Heat shock protein $70,{ }^{2}$ Peroxisome proliferatoractivated receptor gamma, coactivator $1,{ }^{3}$ Carnitine palmitoyltransferase 1 , ${ }^{4}$ Hemoglobin beta chain, ${ }^{5} \mathrm{Hemoglobin}$ alpha chain, ${ }^{6} \mathrm{CD} 8$ alpha $\mathrm{T}$ cell glycoprotein, ${ }^{7} \mathrm{SEC} 13$-like protein, ${ }^{8} \mathrm{NADH}$ dehydrogenase (ubiquinone) 1 beta subcomplex, 8 , $19 \mathrm{kDa},{ }^{9}$ Elongation factor 1 alpha. 
or elongation factor 1 alpha (used for HSP70 only). All reference genes were validated using the BestKeeper software [25]. The efficiency of the PCR reactions was estimated for all primer pairs by six times 1:5 dilution series of a cDNA mix of all used samples. Efficiency values were estimated by using the LightCycler 480 Software (version 1.5.0.39). Differences in gene expression ratios ( $\log _{2}$-transformed values) between groups were assessed by twosided pairwise t-tests with pooled standard deviation and $\mathrm{p}$-value adjustment according to Holm (stats-package in $\mathrm{R}$ version 3.0.2 (http://cran.r-project.org).

\section{Immunofluorescence microscopy}

Hearts were fixed in 4\% PFA (paraformaldehyde) and dehydrated in increasing ethanol concentrations prior to paraffin embedding and sectioning $(7 \mu \mathrm{M})$. After paraffin removal and dehydration, microwave facilitated antigen retrieval was conducted in $10 \mathrm{mM}$ Tris- $\mathrm{Hcl}(\mathrm{pH}=10)$ for $10 \mathrm{~min}$. Permeabilization was achieved with $1 \%$ Triton X100 for 10 min before 2 hrs blocking in 5\% dry milk dissolved in $1 \times$ PBST. Primary antibodies used were rabbit polyclonal antibodies against salmon collagen type I (BioLogo, Kiel, Germany), human/mouse inducible nitric oxide synthase, iNOS (Thermo Fisher Scientific Inc., Rockford, USA) and human/mouse vascular endothelial growth factor, VEGF (147: sc-507, Santa Cruz Biotechnology Inc., Heidelberg, Germany). All were tested for reactivity and specificity in Atlantic salmon [26-28]. Primary antibodies were diluted to a concentration of $5-10 \mu \mathrm{g} / \mathrm{ml}$ in $1 \times$ PBST with $2 \%$ dry milk and $1 \%$ DMSO. After overnight incubation at $4^{\circ} \mathrm{C}$, the sections were washed thoroughly in $1 \times$ PBST and incubated with Alexa conjugated secondary antibodies (Invitrogen) diluted 1:200 for $2 \mathrm{hrs}$ at room temperature. As controls, secondary antibody only was used giving negative results. Final $1 \times$ PBST washes were carried out before mounting and microscopy. All images were captured using a Zeiss Axioplan Z1 and post processed using the Zeiss Axiovison software and Corel Draw. Similar exposure and image manipulation settings were applied to the images to enable comparison between treatments and replicates. A total of three fish (three sections per heart) from each temperature and time point was analyzed. The whole tissue was inspected and one representative image was captured for each section (presented in Figures 1, 2 and 3). For quantification of iNOS expression, the average number of positive cells \pm SEM in spongy myocardium (showing the most prominent staining differences between temperature groups) from all fish was calculated with Zeiss Axiovison software from two field of views per fish ( $25 \times$ objective). For quantification of VEGF expression, the average number of positively stained cells \pm SEM along the entire epicardium from all fish was similarly calculated (two field of views, $25 \times$ objective) and expressed as number of positive cells per mm epicardium. Expression of collagen I between temperature groups was presented as LUT (Look-Up Table) images showing fluorescence intensities of representative sections.

\section{Results}

A salmonid cDNA microarray was used to examine temperature effects on cardiac (ventricle) gene expression in adult Atlantic salmon exposed to $19^{\circ} \mathrm{C}$ (simulating peak summer temperature in Norwegian Atlantic salmon aquaculture) for 21 days (short-term acclimation) and 56 days (long-term acclimation). Temperature affected expression of $11.6 \%$ of the genes, of which 52 genes were up-regulated and 156 genes were downregulated (expression ratio $>1.3 / \log _{2}$ expression ratio $>0.4,19^{\circ} \mathrm{C}$ versus $14^{\circ} \mathrm{C}$ ) in at least one time point. These were further grouped according to functional annotation as shown in Table 2, which provided a fundament for supportive analysis on selected genes and proteins using real-time $\mathrm{qPCR}$ and immunofluorescence microscopy. Up-regulated features included seven genes involved in cell signaling responses to a diverse array of cellular perturbations such as heat stress and unfolded protein response, among them hsp47, hsp90, mapk13, junB (Table 2) and $h s p 70$ (qPCR; Figure 1A). Immunofluorescence microscopy of iNOS indicated staining of a higher number of cells and at stronger levels in the compact and spongy myocardium after 56 days at $19^{\circ} \mathrm{C}$ in comparison to control temperature (Figure 2). Immunostaining of VEGF indicated increased and more evenly distributed staining of cells along the epicardium in $19^{\circ} \mathrm{C}$ fish in comparison to controls, where VEGF was localised in epicardial foci (Figure 3). VEGF labelling was not seen in the compact and spongy muscle layers. Microarray genes coding for structural myocardial proteins showed coordinated down-regulation in fish reared at $19^{\circ} \mathrm{C}$ compared to $14^{\circ} \mathrm{C}$ at both time points (Table 2), including different transcripts for myosin, actin and troponin. Among genes regulating extracellular matrix, metalloproteinase genes, involved in degradation of extracellular matrix, was up-regulated whereas several transcripts for collagens were down-regulated with elevated temperature at both time points (Table 2). In contrast, immunostaining of collagen I indicated increased expression in the epicardium and compact myocardium of $19^{\circ} \mathrm{C}$ versus $14^{\circ} \mathrm{C}$ fish, while no staining was observed in the spongy layer at either temperature (Figure 4). In regard to energy metabolism, mitochondrial electron transport chain genes such as NADH-ubiquinone oxidoreductase $15 \mathrm{kDa}$ subunit, cytochromes $\mathrm{b} / \mathrm{c} / \mathrm{cl} / \mathrm{c} 2$ and ATP synthase were down-regulated with elevated temperature at both time points (Table 2). In addition, genes for cardiac fatty acid oxidation showed significant up-regulation 
Figure 1 Cardiac expression of selected genes in fish reared under normal and elevated temperature. Relative mRNA transcription levels of A) heat shock protein 70, HSP70; B) carnitine palmitoyltransferase 1, CPT1; C) peroxisome proliferator-activated receptor (PPAR)y coactivator 1a, PGC1a; D) a-hemoglobin; E) T cell antigen CD8 alpha in fish reared at normal $\left(14^{\circ} \mathrm{C}\right.$, filled circles) and elevated $\left(19^{\circ} \mathrm{C}\right.$, open circles) temperature for 21 and 56 days. Data are mean $\log _{2}$ expression ratio \pm SEM relative to the average of normalized controls $\left(14^{\circ} \mathrm{C}, 21\right.$ days), real-time $\mathrm{qPCR}$. Statistical differences (adjusted p-value $<0.05$; pairwise t-tests of the four groups, $N=9$ ) are indicated between temperatures (21 days: $a^{*}$, 56 days: $\left.b^{*}\right)$ and time points for $19^{\circ} \mathrm{C}$ fish $\left(c^{*}\right)$.

in $19^{\circ} \mathrm{C}$ fish, including carnitine palmitoyltransferase $(C P T) 1$ after 56 days (Figure 1B) and peroxisome proliferator-activated receptor (PPAR)y coactivator $(P G C)$ $1 \alpha$ after 21 days (Figure $1 C$ ). Genes involved in oxygen transport and the heme biosynthetic pathway, including several transcripts for $\alpha / \beta$-hemoglobin and $d$-aminolevulinate synthase, were down-regulated in $19^{\circ} \mathrm{C}$ fish after 21 and 56 days (Table 2 and Figure 1D). Microarray results indicated that expression of immune-related genes were influenced by the temperature elevation, through downregulation of genes encoding humoral components of the innate immune system (complement factors, chemokines and receptors, the serine protease activator cathepsin $C-3$ and annexin A1). In contrast, genes coding for cellular components were up-regulated, such as CD9 antigen, high affinity IgG Fc receptor I precursor, tyrosine-protein kinase BTK, gamma-interferon inducible lysosomal thiol reductase (Table 2) and the T cell antigen CD8 alpha (Figure 1E).

\section{Discussion}

Seasonal fluctuations in seawater temperature are naturally occurring in the aquaculture of Atlantic salmon. Particularly in the summer months, western and southern regions of Norway experience temperature increments above thermal preference $\left(15^{\circ} \mathrm{C}[3,29,30]\right)$ peaking around $18-20^{\circ} \mathrm{C}$. In a recent study we observed significantly reduced feed intake, growth performance and endogenous energy storage in large $(\sim 2 \mathrm{~kg})$ Atlantic salmon after long-term exposure to $19^{\circ} \mathrm{C}$ under controlled conditions [19]. This poor performance was linked to suppressed endocrine appetite regulation, leading to a negative energy homeostasis with depleted lipid stores in muscle and whole carcass. Based on these findings and the same experimental fish, the current study aimed to further understand how the chronic temperature elevation affected molecular processes at the levels of gene and protein expression in the heart, as a key organ for thermal plasticity and acclimation in salmonids [31,32].

Among genes that were strongly up-regulated with elevated temperature, it was not surprising to find several chaperones and other genes involved in the unfolded protein response. This included three heat shock proteins 

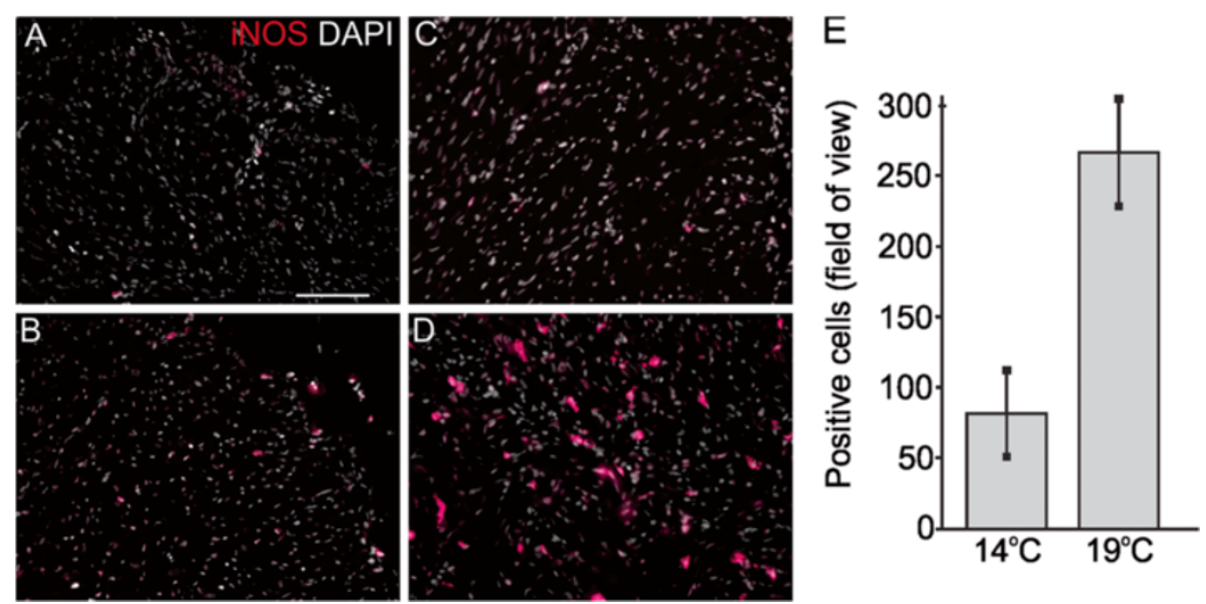

Figure 2 Inducible nitric oxide synthase (iNOS) expression in cardiac tissues of fish reared under normal and elevated temperature. Immunofluorescence staining of iNOS (red color) and DAPI nuclear counterstain (white color) in cardiac tissues of fish reared for 56 days at normal temperature $\left(14^{\circ} \mathrm{C}\right.$, upper panels) and high temperature $\left(19^{\circ} \mathrm{C}\right.$, lower panels). At $14^{\circ} \mathrm{C}$ iNOS is expressed at low levels and in a few cells in the compact (A) and spongy (B) myocardium. At $19^{\circ} \mathrm{C}$ iNOS is expressed in a higher number of cells in the compact myocardium (C), and strong staining of individual myocytes is observed in the spongy myocardium (D). Panels A-D show one representative micrograph of three sections examined per fish from a total of three fish per temperature group. The $40 \mu \mathrm{m}$ scale bar in panel $\mathbf{A}$ applies to all panels in the figure. E: Average number of positive cells \pm SEM in spongy myocardium, calculated using a larger field of view (25× objective).

(HSPs), which are among the most studied proteins in the general response to a variety of stressors and perturbations in mammals and fish [33]. Although their use as suitable indicators of stressed states in fish has been disputed [34], synthesis of HSPs to maintain proper folding/refolding of proteins has been shown highly expensive for the organism [35]. In spite of a severely compromised energy homeostasis in the experimental fish, the sustained induced transcription of HSPs over time could indicate a need for chaperone activity and the unfolded protein response during cardiac acclimation to the elevated temperature.

The nitric oxide synthase system is an important interand intracellular regulator of mechanical performance and oxygen supply in the fish heart [15], and iNOS is exclusively expressed in ventricular cardiomyocytes under basal condition and after LPS stimulation [36]. Although the physiological and pathophysiological regulation of the NOS/NO system is very complex and only partly understood in fish, studies have shown that NOS
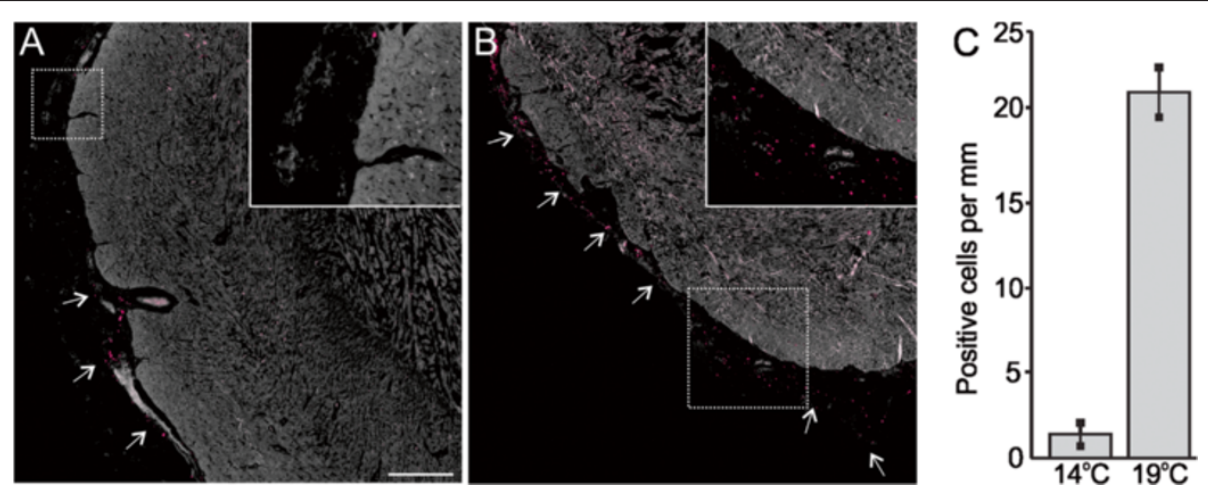

Figure 3 Vascular endothelial growth factor (VEGF) expression in cardiac tissues of fish reared under normal and elevated temperature. Immunofluorescence staining of VEGF (red color) in cardiac tissues of fish reared for 56 days at control temperature $\left(14^{\circ} \mathrm{C}, \mathbf{A}\right)$ and elevated temperature $\left(19^{\circ} \mathrm{C}, \mathbf{B}\right)$. A: VEGF positive cells (arrows) are mainly located around already existing epicardial vasculature at $14^{\circ} \mathrm{C}$. B: VEGF positive cells (arrows) are evenly distributed along the entire epicardium at $19^{\circ} \mathrm{C}$. Panels $\mathbf{A}-\mathbf{B}$ show one representative micrograph of three sections examined per fish from a total of three fish per temperature group, with one representative region per group shown at higher magnification (inset). The $400 \mu \mathrm{m} s c a l e$ bar in panel $\mathbf{A}$ applies to both panels in the figure. $\mathbf{C}$ : Average number of positive cells per $\mathrm{mm}$ epicardium $\pm \mathrm{SEM}$, calculated using a larger field of view (25× objective). 
Table 2 Functional categories and genes regulated in Atlantic salmon reared at high temperature for $\mathbf{2 1}$ and $\mathbf{5 6}$ days identified from microarray analysis

\begin{tabular}{|c|c|c|c|}
\hline Probe number & Name (best blast hit) & Day 21 & Day 56 \\
\hline \multicolumn{4}{|c|}{ Unfolded protein response } \\
\hline CA356940 & Heat shock protein $47 \mathrm{kDa}$ & 1,15 & 1,35 \\
\hline CA373890 & Heat shock protein HSP 90-beta-1 & 0,66 & 0,67 \\
\hline EST1-3A_F08 & Heat shock protein HSP 90-beta-2 & 0,83 & 0,80 \\
\hline EXOB1_E03 & Eukaryotic translation initiation factor 3 subunit 5 & 0,55 & 0,30 \\
\hline EXOB1_E08 & Eukaryotic translation initiation factor 3 subunit 6-1 & 0,44 & 0,35 \\
\hline CA382570 & Mitogen-activated protein kinase 13 & 0,29 & 0,57 \\
\hline EST1-3A_H06 & Transcription factor jun-B-1 & 0,43 & 1,02 \\
\hline CA368716 & Membrane-bound transcription factor site 2 protease & 0,58 & 0,36 \\
\hline CA378435 & Protein phosphatase $2 \mathrm{C}$ delta isoform & 0,62 & 0,23 \\
\hline \multicolumn{4}{|c|}{ Tissue remodeling and cytoskeleton } \\
\hline est03c04 & Matrix metalloproteinase-9 & 0,34 & 0,51 \\
\hline EXOB3_H01 & Matrix metalloproteinase-13 & 0,47 & 0,81 \\
\hline CA378743 & Fibronectin precursor & 0,44 & 0,29 \\
\hline utu04c11 & Collagen alpha $1(I)$ chain-2 & $-0,32$ & $-0,95$ \\
\hline HK0003_C02 & Collagen alpha 1(I) chain-1 & $-0,16$ & $-0,51$ \\
\hline utu02b11 & Collagen a3(I)-2 & $-0,29$ & $-0,56$ \\
\hline utu02a06 & Collagen a3(I)-1 & $-0,22$ & $-0,41$ \\
\hline HKT0001_B03 & Alpha 2 type I collagen-1 & $-0,54$ & $-0,91$ \\
\hline HK0003_E07 & Myosin light chain 2-1 & $-0,50$ & $-0,73$ \\
\hline utu02c02 & Myosin heavy chain 1-1 & $-0,51$ & $-0,54$ \\
\hline utu04f06 & Myosin heavy chain 1-2 & $-0,64$ & $-0,95$ \\
\hline HK0002_F05 & Myosin heavy chain, fetal & $-0,56$ & $-0,50$ \\
\hline HK0002_B06 & Troponin T-3 & $-0,81$ & $-0,67$ \\
\hline HK0003_D01 & Troponin C-1 & $-0,71$ & $-0,17$ \\
\hline HKT0001_E07 & Actin, alpha 1 & -0.39 & -0.71 \\
\hline utu04d04 & Actin, alpha 4 & -0.13 & -0.67 \\
\hline utu04f08 & Actin, alpha 5 & -0.58 & -1.27 \\
\hline HK0003_C08 & Parvalbumin alpha-2 & $-0,78$ & $-0,65$ \\
\hline est01e10 & Tolloid-like protein (nephrosin)-1 & $-0,74$ & $-0,47$ \\
\hline \multicolumn{4}{|c|}{ Energy metabolism } \\
\hline HKT0001_H05 & Cytochrome b-3 & 0,32 & 0,41 \\
\hline utu02b07 & Cytochrome c oxidase subunit II & 0,59 & 0,44 \\
\hline HK0001_G02 & ATP synthase beta chain-2 & $-0,43$ & $-0,71$ \\
\hline HK0002_G02 & Creatine kinase, sarcomeric mitochondrial precursor & $-0,41$ & $-0,63$ \\
\hline est03a08 & Cytochrome c-1 & $-0,66$ & $-0,99$ \\
\hline HK0003_B03 & Cytochrome c-2 & $-0,91$ & $-1,16$ \\
\hline EXOB1_C10 & Cytochrome P450 2 K4-2 & $-0,94$ & $-1,39$ \\
\hline HK0002_A12 & NADH-ubiquinone oxidoreductase $15 \mathrm{kDa}$ subunit & $-0,45$ & $-0,43$ \\
\hline \multicolumn{4}{|l|}{ Heme biosynthesis } \\
\hline EXOB2_B10 & Hemoglobin beta chain Omy 30073 & $-0,54$ & $-1,64$ \\
\hline HST0001_C04 & Hemoglobin alpha chain Omy 11839 & $-0,96$ & $-1,56$ \\
\hline EXOB4_H06 & Alpha-globin 1-3 Omy 8146 & $-0,76$ & $-1,41$ \\
\hline
\end{tabular}


Table 2 Functional categories and genes regulated in Atlantic salmon reared at high temperature for 21 and $\mathbf{5 6}$ days identified from microarray analysis (Continued)

\begin{tabular}{|c|c|c|c|}
\hline HST0001_C02 & Alpha-globin I-1 Omy 11839 & $-0,18$ & $-0,97$ \\
\hline utu01e09 & Embryonic alpha-type globin2 + collagen alpha 2(1) & $-0,43$ & $-0,68$ \\
\hline HST0001_D08 & Beta-globin Omy 9744 & $-0,79$ & $-1,06$ \\
\hline est01g04 & 5-aminolevulinate synthase & 0,08 & $-0,52$ \\
\hline CA381045 & Aminolevulinate, delta-, synthase 1 & $-0,84$ & $-1,23$ \\
\hline HK0001_D09 & Cytochrome P450 2 F1 & $-0,87$ & $-1,15$ \\
\hline \multicolumn{4}{|c|}{ Immune response } \\
\hline EXOB1_F11 & CD9 & 0,45 & 0,36 \\
\hline CA388403 & CD9-like & 0,20 & 0,54 \\
\hline CA378736 & Tyrosine-protein kinase BTK & 0,44 & 0,29 \\
\hline CA382425 & B-cell translocation gene 1-2 & 0,49 & 0,42 \\
\hline EXOB4_C11 & High affinity immunoglobulin $\gamma$ Fc receptor I precursor & 0,47 & 0,39 \\
\hline CA362806 & Gamma-interferon inducible lysosomal thiol reductase & 0,51 & 0,17 \\
\hline CA355488 & Tapasin-2 & 0,40 & 0,45 \\
\hline CA373659 & Mannan-binding lectin serine protease $2-2$ & 0,25 & 0,46 \\
\hline ENH2_B05 & Acute phase protein & 0,41 & 0,53 \\
\hline CA370329 & Lysozyme C precursor & 0,87 & 0,61 \\
\hline CA362419 & Complement component C6 & 0,47 & 0,40 \\
\hline HK0001_F01 & Complement factor $\mathrm{H}-1$ & $-0,82$ & $-0,73$ \\
\hline CA370696 & Complement control protein factor I-B & $-0,71$ & 0,23 \\
\hline EXOB1_E12 & Serine protease-like protein-3 & $-0,34$ & $-0,53$ \\
\hline EST1-3A_A09 & Serine protease-like protein-2 & $-0,42$ & $-0,65$ \\
\hline EXOB3_B01 & Cathepsin C-3 & $-0,90$ & $-1,30$ \\
\hline CA377504 & Cold autoinflammatory syndrome 1 protein & $-0,81$ & $-0,62$ \\
\hline HK0002_G10 & T-cell receptor a chain $\mathrm{V}$ region HPB-MLT precursor (Fr) & $-0,91$ & $-0,52$ \\
\hline CA372428 & Leukotriene B4 receptor 1 & $-1,11$ & $-0,82$ \\
\hline HK0002_G11 & Myristoylated alanine-rich protein kinase C substrate & $-1,07$ & $-0,87$ \\
\hline EXOB2_G01 & Leukocyte cell-derived chemotaxin 2 & $-0,97$ & $-0,86$ \\
\hline CA343700 & CXC chemokine receptor transcript variant B & $-0,52$ & $-0,88$ \\
\hline CA361151 & Annexin A1-2 & $-0,58$ & $-0,47$ \\
\hline
\end{tabular}

Expression values are $\log _{2}$-expression ratios $\left(19^{\circ} \mathrm{C}\right.$ versus $\left.14^{\circ} \mathrm{C}\right)$ from analysis of pooled heart samples (per temperature treatment: 3 fish per triplicate tanks, $\left.n=9\right)$.

influences cardiac inotropy (i.e. cardiac output) of salmon [37] and the red-blooded icefish T. bernacchii [36], which was also sensitive to acute temperature change [16]. Our results showing increased immunofluorescence staining of iNOS in compact and spongy myocardium may be a further indication of an involvement in the thermal acclimation or response to increased temperature. NO has also been shown to induce vasodilation and reduce coronary resistance under hypoxia in salmonids [38]. In this process, VEGF is another important regulator which promotes proliferation and migration of endothelial cells in the formation of new blood vessels under cardiac physiological and pathological conditions [39]. Whether the induced expression of VEGF and iNOS in our study reflected increased vascularization and/or vasodilation to compensate for increased oxygen demand with elevated temperature should be subject to further study. In this regard, the lower abundance of several transcripts for heme biosynthesis and ATP production/energy metabolism after short- and long-term exposure to elevated temperature could also indicate that oxygen transport/uptake and possibly aerobic metabolism was affected.

A fundamental mode for increasing oxygen carrying capacity in vertebrates is by increasing the cardiac output. In salmonids, several studies have suggested that a limitation at the level of the heart is the primary cause of limited oxygen supply with increasing temperature because maximum cardiac output fails to increase above thermal optimum [13]. Furthermore, acclimation to high temperatures has been associated with increased thickness 

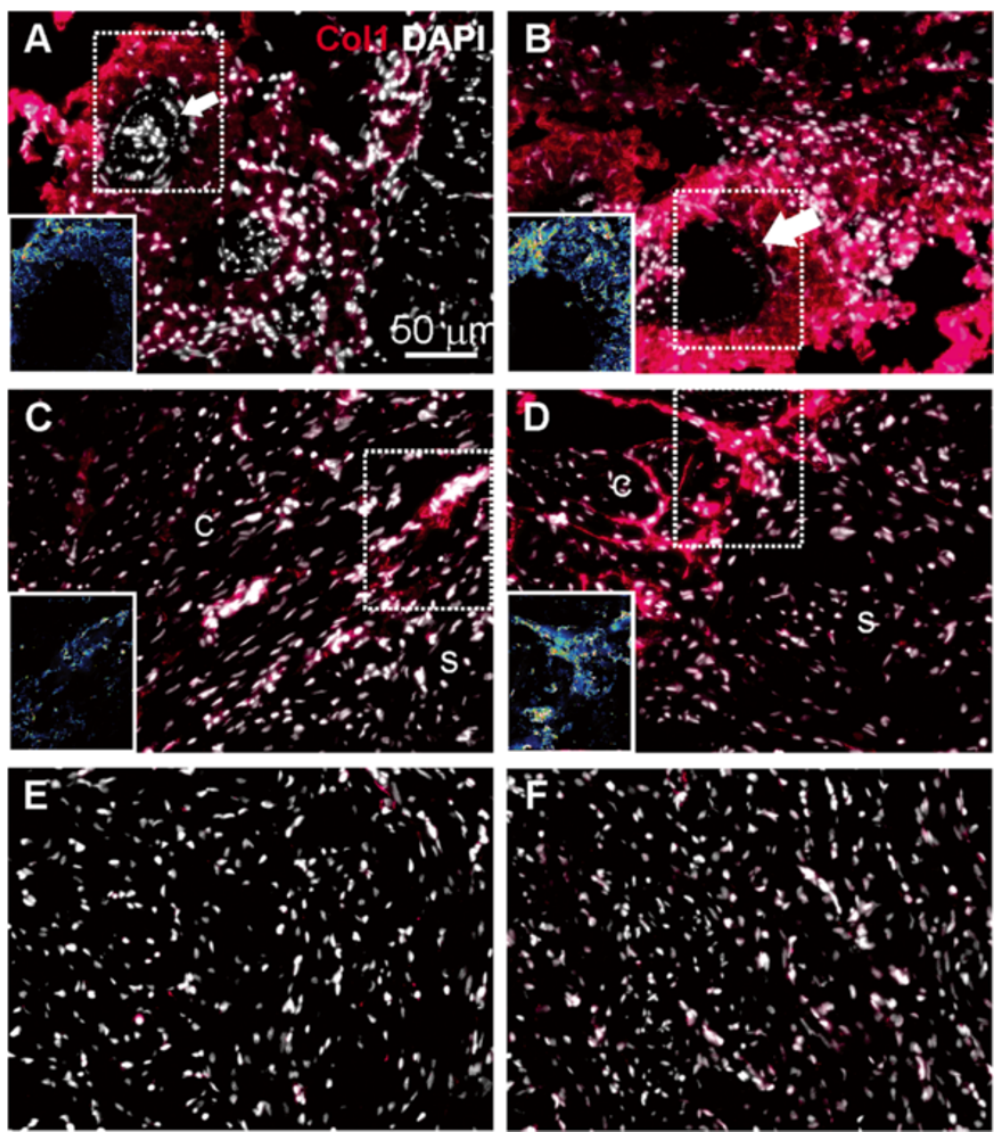

Figure 4 Collagen I expression in cardiac tissues of fish reared at normal and elevated temperature. Immunofluorescence staining of collagen I (red color) and DAPI nuclear counterstain (white color) in cardiac tissues of fish reared for 56 days at $14^{\circ} \mathrm{C}$ (left panels, $\left.\mathbf{A}, \mathbf{C}, \mathbf{E}\right)$ and $19^{\circ} \mathrm{C}$ (right panels, B, D, F). A: Collagen I is abundant in the epicardium and vasculature (arrow) at $14^{\circ} \mathrm{C}$. B: Increased signal intensity is observed at $19^{\circ} \mathrm{C}$. C: At $14^{\circ} \mathrm{C}$ collagen I is expressed in cell clusters in the compact (c) but not in the spongy (s) myocardium. $\mathbf{D}$ : At $19^{\circ} \mathrm{C}$ collagen I is strongly expressed in larger structures resembling connective tissue of the compact (c) but not in the spongy (s) myocardium. E-F: Cells in the spongy myocardium show weak staining at both temperatures. Fluorescence intensities are shown as LUT (Look-Up Table) images in panels A-D (inset). Panels show one representative micrograph of three sections examined per fish from a total of three fish per temperature group. The $50 \mu \mathrm{m}$ scale bar in panel $\mathbf{A}$ applies to all panels in the figure.

of the compact myocardium, which is assumed to compensate for the decreased power-generating ability [14] or simply reflecting an increased activity level at higher temperatures [40]. A recent study with warm-acclimated rainbow trout also reported that the increased thickness of the compact layer was associated with reduced connective tissue, however this was only observed for male and not female fish [10]. Correspondingly, we observed lower abundance of collagen mRNA with high temperature, however effects of sex was not determined. On the contrary, immunostaining demonstrated increased deposition of collagen I in large bundles exclusively in the compact myocardium at high temperature. This discrepancy between protein and transcript levels of collagen could be methodology based, since gene expression was measured in total RNA extracted from the whole myocardium (both spongy and compact layers) whereas immunofluorescence detection of collagen showed increased staining with temperature only in the compact myocardium, which typically comprises $30-50 \%$ of the heart in athletic fishes [7]. In fact, Klaiman et al. [10] reported reduction in muscle bundle area in spongy myocardium with warm acclimation, thus lower collagen gene expression levels could simply reflect altered proportions of compartments with increased temperature. Pointing in the same direction, we also observed substantially lower transcript levels of several cytoskeleton genes including actin, myosin and troponin after short- and long-term acclimation. In view of the severely compromised growth performance and energy homeostasis of the fish in this study after long-term high temperature, implications of the compact myocardium increase in collagen I protein expression on cardiac function and possibly fibrosis should be further studied. Reduced mitochondrial capacity above thermal optimum has been demonstrated for fish [41]. Interestingly, we found significantly higher mRNA levels of CPT1 (after 56 days) and 
PGC1 $\alpha$ (after 21 days) in fish kept at $19^{\circ} \mathrm{C}$. It could be speculated whether this was a tissue response in order to balance the overall energetic status, a notion supported from reduced hepatic beta-oxidation in the same fish [19].

High temperature affected cardiac expression of important immune-related genes. The salmon heart is an immune-relevant organ in the sense that it represents a major replication site for several viral pathogens of high importance $[17,18]$. Common for these diseases is the strong inflammation of the myocardium which coincides with a strong activation of a CD8 $\mathrm{T}$ cell response $[18,23,42]$. Consequently, given the temperature-induced gene expression of cellular immune components including CD8 alpha in the present study, it may be speculated if high seawater temperatures can further elevate myocardial inflammation during infection and thus represent a relevant risk factor affecting disease outcome. It has been proposed that low environmental temperature diminishes the humoral immune response, since primary antibody response has been found to be either dampened or retarded at lower temperatures $[43,44]$. Here, we report that expression of some genes involved in the innate humoral immune response were down-regulated with high temperature. At the same time, a suite of genes representing cellular components were up-regulated, including some involved in B- and T-cell development. Our understanding of immunological effects of elevated temperatures in fish is far from complete, but studies have shown significant hematological modulation in response to thermal acclimation in salmonids [45-47]. A study with rainbow trout reported induced complement lytic activity and opsonization capacity with increased temperature in rainbow trout [48], which could agree with our finding of temperature-induced gene expression of complement C6, a part of the membrane attack complex. Another aspect relates to whether our observed regulation of cardiac innate immune response genes is ascribed to the temperature increase per se or (re)allocation of resources in view of the negative growth performance and energy homeostasis of the fish. This is a subject that should deserve attention in future research.

\section{Conclusions}

This study provides new knowledge on the molecular responses of cardiac tissues during long-term exposure to elevated seawater temperature reflective of the peak summer temperatures experienced in Atlantic salmon aquaculture. We report temperature-induced changes in expression of genes and proteins indicating that the unfolded protein response, vascularization and remodeling of connective tissue as well as altered innate immune responses were affected during cardiac acclimation to elevated temperature.
Competing interests

The authors declare that they have no competing interests.

\section{Authors' contributions}

SMJ designed and performed the microarray studies together with AK, and participated in samplings, data interpretation and wrote the manuscript together with VC, who also performed qPCR gene expression studies together with GT. AK were responsible for microarray data processing and analysis as well as revision of the manuscript. JT conducted immunofluorescence microscopy. HT obtained funding, planned and coordinated the experimental fish study and participated in samplings together with $\mathrm{EMH}, \mathrm{TJ}, \mathrm{SS}$ and $\mathrm{OB}$, and also revised the manuscript. All authors read and approved the final manuscript.

\section{Acknowledgements}

The study was supported by the Research Council of Norway, grant nos. 187306/S40 and 225219/E40, and The Norwegian Seafood Research Fund (FHF) grant no. 900870. We wish to thank Katrine Hånes Kirste and Hege Munck for laboratory assistance.

\section{Author details}

${ }^{1}$ Nofima AS, P.O. Box 210, N-1431 Ås, Norway. ${ }^{2}$ AVS Chile S.A., Casilla 300, Puerto Varas, Chile. ${ }^{3}$ National Institute of Nutrition and Seafood Research (NIFES), P.O. Box 2029, N-5817 Bergen, Nordnes, Norway. ${ }^{4}$ Institute of Marine Research, Matre Research Station, N-5984 Matredal, Norway. ${ }^{5}$ Skretting Norway AS, P.O. Box 319, Sentrum N-4002 Stavanger, Norway. ${ }^{6}$ Marine Harvest Norway AS, Sandviksbodene 78, N-5035 Bergen, Norway.

Received: 15 August 2013 Accepted: 21 February 2014

Published: 1 March 2014

\section{References}

1. Brett JR: Energetic responses of salmon to temperature. A study of some thermal relations in the physiology and freshwater ecology of sockeye salmon (Oncorhynchus nerka). Am Zool 1971, 11:99-113.

2. Fry FEJ: The effect of environmental factors on the physiology of fish. In Fish Physiology. Edited by Hoar WD, Randall DJ. New York: Academic; 1971.

3. Handeland SO, Bjornsson BT, Arnesen AM, Stefansson SO: Seawater adaptation and growth of post-smolt Atlantic salmon (Salmo salar) of wild and farmed strains. Aquaculture 2003, 220(1-4):367-384.

4. Jonsson $\mathrm{B}$, Jonsson $\mathrm{N}$ : A review of the likely effects of climate change on anadromous Atlantic salmon Salmo salar and brown trout Salmo trutta, with particular reference to water temperature and flow. J Fish Biol 2009, 75(10):2381-2447.

5. Claireaux G, Webber DM, Lagardere JP, Kerr SR: Influence of water temperature and oxygenation on the aerobic metabolic scope of Atlantic cod (Gadus morhua). J Sea Res 2000, 44(3-4):257-265.

6. Farrell AP, Richards JJ: Defining hypoxia: an integrative synthesis of the responses of fish to hypoxia. In Hypoxia. Edited by Richards JG, Farrell AP, Brauner CJ. Burlington: Academic; 2009.

7. Farrell AP, Eliason EJ, Sandblom E, Clark TD: Fish cardiorespiratory physiology in an era of climate change. Can J Zool 2009, 87(10):835-851.

8. Goldspink G: Adaptation of fish to different environmental-temperature by qualitative and quantitative changes in gene-expression. J Thermal Biol 1995, 20(1-2):167-174.

9. Hazel JR, Prosser CL: Molecular mechanisms of temperature compensation in poikilotherms. Physiol Rev 1974, 54(3):620-677.

10. Klaiman JM, Fenna AJ, Shiels HA, Macri J, Gillis TE: Cardiac remodeling in fish: strategies to maintain heart function during temperature change. Plos One 2011, 6(9):e24464.

11. Lee CG, Farrell AP, Lotto A, MacNutt MJ, Hinch SG, Healey MC: The effect of temperature on swimming performance and oxygen consumption in adult sockeye (Oncorhynchus nerka) and coho (O-kisutch) salmon stocks. $J$ Exp Biol 2003, 206(18):3239-3251.

12. Gamperl AK, Farrell AP: Cardiac plasticity in fishes: environmental influences and intraspecific differences. J Exp Biol 2004, 207(15):2539-2550.

13. Steinhausen MF, Sandblom E, Eliason EJ, Verhille C, Farrell AP: The effect of acute temperature increases on the cardiorespiratory performance of resting and swimming sockeye salmon (Oncorhynchus nerka). J Exp Biol 2008, 211(24):3915-3926 
14. Farrell AP, Gamperl AK, Hicks JMT, Shiels HA, Jain KE: Maximum cardiac performance of rainbow trout (Oncorhynchus mykiss) at temperatures approaching their upper lethal limit. J Exp Biol 1996, 199(3):663-672.

15. Tota B, Amelio D, Pellegrino D, Ip YK, Cerra MC: NO modulation of myocardial performance in fish hearts. Comp Biochem Phys A 2005, 142(2):164-177.

16. Amelio D, Garofalo F, Capria C, Tota B, Imbrogno S: Effects of temperature on the nitric oxide-dependent modulation of the Frank-Starling mechanism: the fish heart as a case study. Comp Biochem Phys A 2013 164(2):356-362.

17. Haugland $O$, Mikalsen AB, Nilsen P, Lindmo K, Thu BJ, Eliassen TM, Roos N, Rode $\mathrm{M}$, Evensen $\mathrm{O}$ : Cardiomyopathy syndrome of Atlantic salmon (Salmo salar L.) is caused by a double-stranded RNA virus of the Totiviridae family. J Virol 2011, 85(11):5275-5286.

18. Mikalsen AB, Haugland O, Rode M, Solbakk IT, Evensen O: Atlantic salmon reovirus lifection causes a CD8 T cell myocarditis in Atlantic salmon (Salmo salar L.). Plos One 2012, 7(6):e37269.

19. Hevroy EM, Waagbo R, Torstensen BE, Takle H, Stubhaug I, Jorgensen SM, Torgersen T, Tvenning L, Susort S, Breck O, Hansen T: Ghrelin is involved in voluntary anorexia in Atlantic salmon raised at elevated sea temperatures. Gen Comp Endocrinol 2012, 175(1):118-134.

20. Schiotz BL, Jorgensen SM, Rexroad C, Gjoen T, Krasnov A: Transcriptomic analysis of responses to infectious salmon anemia virus infection in macrophage-like cells. Virus Res 2008, 136(1-2):65-74.

21. Krasnov A, Timmerhaus G, Afanasyev S, Jorgensen SM: Development and assessment of oligonucleotide microarrays for Atlantic salmon (Salmo salar L.). Comp Biochem Physiol Part D Genomics Proteomics 2011 6(1):31-38.

22. Bustin SA, Benes V, Garson JA, Hellemans J, Huggett J, Kubista M, Mueller R, Nolan T, Pfaffl MW, Shipley GL, Vandesompele J, Wittwer CT: The MIQE guidelines: minimum information for publication of quantitative real-time PCR experiments. Clin Chem 2009, 55(4):611-622.

23. Timmerhaus G, Krasnov A, Nilsen P, Alarcon M, Afanasyev S, Rode M, Takle $H$, Jorgensen SM: Transcriptome profiling of immune responses to cardiomyopathy syndrome (CMS) in Atlantic salmon. BMC Genomics 2011, 12:459.

24. Pfaffl MW, Horgan GW, Dempfle L: Relative expression software tool (REST (c)) for group-wise comparison and statistical analysis of relative expression results in real-time PCR. Nucleic Acids Res 2002, 30(9):e36.

25. Pfaffl MW, Tichopad A, Prgomet C, Neuvians TP: Determination of stable housekeeping genes, differentially regulated target genes and sample integrity: BestKeeper - Excel-based tool using pair-wise correlations. Biotechnol Lett 2004, 26(6):509-515.

26. Ebbesson LE, Tipsmark CK, Holmqvist B, Nilsen T, Andersson E, Stefansson SO, Madsen SS: Nitric oxide synthase in the gill of Atlantic salmon: colocalization with and inhibition of $\mathrm{Na}+, \mathrm{K}+-$-ATPase. J Exp Biol 2005, 208(6):1011-1017.

27. Vuori KAM, Soitamo A, Vuorinen PJ, Nikinmaa M: Baltic salmon (Salmo salar) yolk-sac fry mortality is associated with disturbances in the function of hypoxia-inducible transcription factor (HIF-1 alpha) and consecutive gene expression. Aquat Toxicol 2004, 68(4):301-313.

28. Ytteborg E, Torgersen JS, Pedersen ME, Helland SJ, Grisdale-Helland B, Takle $\mathrm{H}$ : Exercise induced mechano-sensing and Substance $\mathrm{P}$ mediated bone modeling in Atlantic salmon. Bone 2013, 53(1):259-268.

29. Handeland SO, Imsland AK, Stefansson SO: The effect of temperature and fish size on growth, feed intake, food conversion efficiency and stomach evacuation rate of Atlantic salmon post-smolts. Aquaculture 2008, 283(1-4):36-42.

30. Hevroy EM, Hunskar C, de Gelder S, Shimizu M, Waagbo R, Breck O, Takle H, Sussort S, Hansen T: GH-IGF system regulation of attenuated muscle growth and lipolysis in Atlantic salmon reared at elevated sea temperatures. J Comp Physiol B-Biochem Syst Environ Physiol 2013, 183(2):243-259.

31. Anttila K, Casselman MT, Schulte PM, Farrell AP: Optimum temperature in juvenile salmonids: connecting subcellular indicators to tissue function and whole-organism thermal optimum. Physiol Biochem Zool 2013, 86(2):245-256.

32. Anttila K, Dhillon RS, Boulding EG, Farrell AP, Glebe BD, Elliott JAK, Wolters WR, Schulte PM: Variation in temperature tolerance among families of Atlantic salmon (Salmo salar) is associated with hypoxia tolerance, ventricle size and myoglobin level. J Exp Biol 2013, 216(7):1183-1190.
33. Iwama GK, Vijayan MM, Forsyth RB, Ackerman PA: Heat shock proteins and physiological stress in fish. Am Zool 1999, 39(6):901-909.

34. Iwama GK, Afonso LOB, Todgham A, Ackerman P, Nakano K: Are hsps suitable for indicating stressed states in fish? J Exp Biol 2004, 207(1):15-19.

35. Houlihan DF: Protein turnover in ectotherms and its relationship to energetics. In Advances in comparative and environmental physiology. Edited by Gilles R. Berlin: Springer; 1991.

36. Garofalo F, Amelio D, Cerra MC, Tota B, Sidell BD, Pellegrino D: Morphological and physiological study of the cardiac NOS/NO system in the Antarctic $(\mathrm{Hb}(-) / \mathrm{Mb}(-))$ icefish Chaenocephalus aceratus and in the red-blooded Trematomus bernacchii. Nitric Oxide-Biol Ch 2009, 20(2):69-78.

37. Gattuso A, Mazza R, Imbrogno S, Sverdrup A, Tota B, Nylund A: Cardiac performance in Salmo salar with infectious salmon anaemia (ISA): putative role of nitric oxide. Dis Aquat Organ 2002, 52(1):11-20.

38. Agnisola C: Role of nitric oxide in the control of coronary resistance in teleosts. Comp Biochem Phys A 2005, 142(2):178-187.

39. Yancopoulos GD, Davis S, Gale NW, Rudge JS, Wiegand SJ, Holash J: Vascular-specific growth factors and blood vessel formation. Nature 2000, 407(6801):242-248.

40. Farrell AP, Hammons AM, Graham MS, Tibbits GF: Cardiac growth in rainbow trout, Salmo gardnieri. Can J Zool 1988, 66(11):2368-2373.

41. Portner HO, Lannig G: Oxygen and capacity limited thermal tolerance. In Hypoxia. Edited by Richards JG, Farrell AP, Brauner CJ. Burlington: Academic; 2009.

42. Timmerhaus G, Krasnov A, Takle H, Afanasyev S, Nilsen P, Rode M, Jorgensen SM: Comparison of Atlantic salmon individuals with different outcomes of cardiomyopathy syndrome (CMS). BMC Genomics 2012, 13:205.

43. Avtalion RR: Temperature effect on antibody production and immunological memory, in carp (Cyprinus carpio) immunized against bovine serum albumin (BSA). Immunology 1969, 17(6):927-931.

44. Rijkers GT, Frederixwolters EMH, Vanmuiswinkel WB: The immune-system of cyprinid fish - kinetics and temperature-dependence of antibodyproducing cells in carp (Cyprinus carpio). Immunology 1980, 41(1):91-97.

45. Hardie LJ, Fletcher TC, Secombes CJ: Effect of temperature on macrophage activation and the production of macrophage activating factor by rainbow-trout (Oncorhynchus mykiss) leukocytes. Dev Comp Immunol 1994, 18(1):57-66.

46. Houston AH, Dobric N, Kahurananga R: The nature of hematological response in fish - Studies on rainbow trout Oncorhynchus mykiss exposed to simulated winter, spring and summer conditions. Fish Physiol Biochem 1996, 15(4):339-347.

47. Pettersen EF, Bjorlow I, Hagland TJ, Wergeland HI: Effect of seawater temperature on leucocyte populations in Atlantic salmon post-smolts. Vet Immunol Immunopathol 2005, 106(1-2):65-76.

48. Nikoskelainen S, Bylund G, Lilius EM: Effect of environmental temperature on rainbow trout (Oncorhynchus mykiss) innate immunity. Dev Comp Immunol 2004, 28(6):581-592

doi:10.1186/1472-6793-14-2

Cite this article as: Jørgensen et al:: Cardiac responses to elevated seawater temperature in Atlantic salmon. BMC Physiology 2014 14:2.

\section{Submit your next manuscript to BioMed Central and take full advantage of:}

- Convenient online submission

- Thorough peer review

- No space constraints or color figure charges

- Immediate publication on acceptance

- Inclusion in PubMed, CAS, Scopus and Google Scholar

- Research which is freely available for redistribution 